\title{
RAZVOJ INSTITUCIONALNOG USTROJA HRVATSKE POLITIKE STRUKOVNOG OBRAZOVANJA
}

\author{
Nikola Buković1 \\ Fakultet političkih znanosti Zagreb
}

\begin{abstract}
SAŽETAK
Zbog nepostojanja odgovarajuće teorijsko-konceptualne podloge relevantna analiza institucionalnih odrednica hrvatske politike strukovnog obrazovanja zahtijeva razvoj zasebnog, prilagođenog eksplanatornog modela. Stoga autor, uz odgovarajuće modifikacije, koristi široko prihvaćen okvir političke ekonomije razvoja vještina za stvaranje kodne liste koju primjenjuje na sve normativne i strateško-programske dokumente koji su uređivali hrvatski sustav strukovnog obrazovanja od neovisnosti do danas. Rezultati kvalitativne analize ukazuju kako je postojeći sustav hrvatskog strukovnog obrazovanja moguće opisati kao „državni s elementima krnje kolektivnosti u području obrazovanja za obrte“; dok je ključni mehanizam njegova stvaranja i održavanja prikladno nazvati „slojevanjem bez promjene institucionalne jezgre”. Empirijsko testiranje ovog mehanizma može bitno produbiti razumijevanje hrvatske politike strukovnog obrazovanja, ali i predstavljati osnovu ambicioznijeg komparativnog istraživanja politike strukovnog obrazovanja u postkomunističkim društvima.
\end{abstract}

KLJUČNE RIJEČI: javne politike, strukovno obrazovanje, razvoj vještina, Hrvatska

\section{Kontakt autora:}

Nikola Buković, doktorski student. Fakultet političkih znanosti, Lepušićeva 6, 10 ooo Zagreb. e-pošta: bukovic.nikola@gmail.com.

1 Autor je polaznik doktorskog studija „Politologija” na Fakultetu političkih znanosti Sveučilišta u Zagrebu. Potvrđuje da je predani rad u cijelosti njegovo autorsko djelo, te preuzima punu odgovornost za moguće nedorečenosti i propuste, uz zahvale Teu Matkoviću i Andriji Henjaku na konstruktivnom komentiranju ranijih verzija, kao i anonimnim recenzentima čiji su osvrti bitno unaprijedili kvalitetu završne verzije. 


\section{UVOD}

Ključni stupovi srednjeg obrazovanja u Hrvatskoj su tri skupine programa koje su u netom završenoj školskoj godini 2018/2019. obuhvatili ukupno oko $98 \%$ učenika koji su po prvi puta upisali prvi razred srednje škole (Ministarstvo znanosti i obrazovanja - MZO 2019). Radi se o općeobrazovnim, odnosno gimnazijskim programima; četverogodišnjim strukovnim, odnosno „tehničarskim” programima; te trogodišnjim strukovnim programima, koji se tradicionalno dijele na one u kojima se učenici obrazuju za zanimanja u obrtu, te one u kojima se učenici obrazuju za zanimanja u industriji i prodaji. Ovaj ustroj se neće detaljnije razlagati s obzirom da predstavlja svojevrsno opće mjesto ne samo stručnoj, već i široj javnosti. Datira iz sad već davne 1992. i Zakona o srednjem školstvu (Hrvatski sabor 1992), te je u literaturi već u više navrata precizno razložen (Matković i sur. 2013; Cedefop ReferNet Croatia 2014; Buković 2018). Manje je poznato da ovakav ustroj zapravo datira iz Općeg zakona o školstvu iz 1958. (Matković 2011, 96). Takva situacija je tim više zanimljiva uzme li se u obzir vrlo eksplicitno i radikalno nastojanje da se u periodu od 1975. do 1991. takav sustav razmontira kroz model usmjerenog strukovnog obrazovanja koji je u osnovi ukinuo razliku između općeg i strukovnog obrazovanja i sve srednjoškolske programe ustrojio na način da obuhvaćaju dvije godine općeg uvoda, nakon čega se učenike pripremalo za konkretne poslove (Bačević 2016, 78-9).

U današnjem sustavu srednjeg obrazovanja u Hrvatskoj najveći broj učenika u Hrvatskoj upisuje srednjoškolske strukovne programe - oko $68 \%{ }^{2}$ u školskoj godini 2018/2019. (MZO 2019). Osnovu za takvu snažno „strukovnu" orijentaciju srednjeg obrazovanja nije lako pronaći u povoljnim javnopolitičkim ishodima. Primjerice, kad se govori o prvoj podskupini trogodišnjih strukovnih programa - onih koji su usmjereni na zanimanja u industriji i prodaji; Crnković Pozaić (2009: 14) upozorava da je urušavanje hrvatske industrijske baze uvelike pod znak pitanja dovelo njihovu održivost, odnosno dostupnost radnih mjesta za mlade s takvim tipom srednjoškolskih kvalifikacija. Kada govorimo o drugoj podskupini trogodišnjih programa, onim za obrtnička zanimanja, utemeljeno je pretpostaviti

2 Od toga $45 \%$ otpada na četverogodišnje „tehničarske programe”, dok se za trogodišnje strukovne programe odlučilo nešto više od $23 \%$ onih koji po prvi puta upisuju srednju školu.

3 Treba naglasiti kako je takva „strukovna orijentacija” još donedavno bila još i bitno izraženija. Konkretno, broj upisanih u trogodišnje programe je u periodu 1998-20o8. pao za $36 \%$; dok je broj upisanih u gimnazije i „tehničarske programe” ostao relativno stabilan. Ovakav ishod se u prvom redu može dovesti u red s demografskim promjenama (pad veličine upisnih generacija), ali i sve izraženijom negativnom selekcijom u trogodišnjim programima (Matković 2011, 123). 
da proaktivna uloga Hrvatske obrtničke komore (nadalje: HOK) u njihovoj izvedbi pozitivno utječe na njihovu tržišnu relevantnost. Međutim, Matković i suradnici $(2013: 6,17)$ utvrđuju izrazito negativan utjecaj krize na dostupnost (kvalitetne) izvanškolske prakse uslijed činjenice da su njome posebice bile pogođene djelatnosti u obrtu. Postojeća istraživanja utvrđuju raširenu praksu kršenja obveza poslodavaca u pogledu isplate naknade naučnicima (Herceg 2010, 26; Matković i sur. 2013, 24). Niti četverogodišnji strukovni programi nisu lišeni ozbiljnih poteškoća. Jokić i Ristić Dedić (2014: 66-67) utvrđuju kako čak dvije trećine učenika koji završavaju ove programe upisuje visoko obrazovanje. Ovakav podatak nameće pitanje upisuju li mladi ovakve programe primarno kao pripremu za rad u određenom zanimanju (što je jedno od bitnih obilježja strukovne orijentacije programa) ili kao alternativnu rutu za visoko obrazovanje u slučaju da ne uspiju upisati gimnazije.

Postojeći teorijsko-konceptualni okviri koji mogu poslužiti komparativnom analiziranju sustava srednjeg strukovnog obrazovanja (Greinert 2004; Rauner 2006; Busemeyer and Trampusch 2012) u svom izvornom obliku ne mogu ponuditi zadovoljavajuće objašnjenje hrvatskog slučaja. To je u prvom redu posljedica činjenice da su takvi okviri razvijeni u kontekstu, a onda i za potrebe, razumijevanja sustava strukovnog obrazovanja u razvijenim industrijskim demokracijama; ne tranzicijskom, postkomunističkom društvu poput hrvatskog. Kvalitetno razumijevanje hrvatske politike strukovnog obrazovanja pretpostavlja razvoj zasebnog, prilagođenog eksplanatornog modela koji je nakon toga potrebno testirati u praksi. To zahtijeva da se unatoč prethodno iznesenim ograničenjima u prvom koraku analiza osloni na jedan od široko prihvaćenih teorijskokonceptualnih okvira kako bi nalazi bili relevantni široj istraživačkoj zajednici. Ovaj rad rekapitulira dosadašnji napredak i ukazuje na sljedeće korake u razvoju takvog modela.

Radi se o problemu koji je vrlo relevantan kako s akademskog tako i šireg društvenog aspekta. Sustavi strukovnog obrazovanja igraju važnu ulogu u političkoj ekonomiji modernog kapitalizma, te uvelike utječu na razvojne kapacitete društava (Hall and Soskice 2001; usporedi s Cvijanović and Redžipegić 2011). Strukovno obrazovanje predstavlja i važan element svake smislene strategije inkluzivnosti u obrazovanju s obzirom da $\mathrm{u}$ pravilu natprosječno koncentrira učenike u najvećem riziku od isključenosti (Doolan, Lukić and Buković 2016). Konačno, razumijevanje hrvatskog slučaja može biti dobra početna točka razvoja šireg programa komparativnog istraživanja sustava strukovnog obrazovanja postkomunističkih/ tranzicijskih država koje često dijele sličan institucionalni ustroj (Kogan 2008), ali i izazove u provedbi učinkovitih reformi (Milovanovitch, Badescu and Prina 2018). 
Rad nakon uvodnog poglavlja razlaže konceptualni okvir i metode prikupljanja podataka. Slijedi predstavljanje i diskusija najznačajnijih nalaza. U zaključnom se poglavlju uz rekapitulaciju rezultata analize razmatra i moguće smjerove daljnjeg istraživanja u ovom području.

\section{KONCEPTUALIZACIJA, METODE PRIKUPLJANJA, TE PROCEDURE ANALIZE PODATAKA}

Pristup razvoju specifičnog eksplanatornog modela koji može kvalitetno protumačiti „hrvatski slučaj” kreće od odabira prikladne i široko prepoznate teorijske podloge. Takva odluka je uvjetovana potrebom da se slučaj opiše na način koji je razumljiv i zanimljiv široj akademskoj javnosti. U tu svrhu se ovdje koristi konceptualni model poznat kao politička ekonomija razvoja vještina najjasnije artikulirana tipologijom koju su razvili Busemeyer i Trampusch (2012: 12; Buković 2018). Temeljem brojnih istraživanja provedenih u razvijenim industrijskim demokracijama, Busemeyer i Trampusch utvrđuju dvije osnovne dimenzije koje uvjetuju strukturu sustava razvoja vještina: i) spremnost države da sudjeluje u razvoju strukovnog obrazovanja i osposobljavanja, te ii) uključenost poslodavaca (tvrtki) u izvedbu početnog srednjoškolskog strukovnog obrazovanja i usavršavanja.

Time nastaju četiri tipa sustava:

1) državni, kojeg karakterizira visoka spremnost države/niska uključenost poslodavaca;

2) liberalni, u kojem su obje dimenzije slabo naglašene;

3) segmentalistički, kojeg karakterizira niska spremnost države te visoka uključenost poslodavaca;

4) kolektivni sustav razvoja vještina u kojem su obje dimenzije snažno naglašene. Niže se nalazi tablični prikaz tipologije, pri čemu su karakteristične zemlje pridružene svakom od tipova.

Struktura pojedinog tipa razvoja vještina se, prema Busemeyer i Trampush (2012: 16), može razumjeti kroz odgovore na 4 temeljna pitanja, za koje svaki od četiri gorenavedena tipa nudi različite tipične odgovore: 
Tablica 1. Tipologija sustava razvoja vještina u razvijenim industrijskim demokracijama

\begin{tabular}{|l|l|l|l|}
\hline $\begin{array}{l}\text { Spremnost } \\
\text { države da } \\
\text { sudjeluje }\end{array}$ & Visoka & $\begin{array}{l}\text { Državni sustavi (Švedska/ } \\
\text { Francuska) }\end{array}$ & $\begin{array}{l}\text { Kolektivni sustavi } \\
\text { (Njemačka, Austrija, } \\
\text { strukovnog } \\
\text { obrazovanja i } \\
\text { osposobljavanja }\end{array}$ \\
\cline { 2 - 4 } & Niska & $\begin{array}{l}\text { Liberalni sustavi } \\
\text { (Sjedinjene Američke } \\
\text { Države, Irska, Ujedinjeno } \\
\text { Kraljevstvo) }\end{array}$ & $\begin{array}{l}\text { Segmentalistički sustavi } \\
\text { (Japan) }\end{array}$ \\
\hline \multicolumn{2}{|c|}{ Niska } \\
$\begin{array}{l}\text { Uključenost poslodavaca (tvrtki) u izvedbu početnog srednjoškolskog } \\
\text { strukovnog obrazovanja }\end{array}$ \\
\hline
\end{tabular}

Izvor: Busemeyer i Trampusch (2012: 12)

1) Tko kontrolira razvoj sustava vještina?

2) Tko provodi programe razvoja vještina?

3) Tko plaća za razvoj vještina?

4) Kakav je odnos između općeg i strukovnog obrazovanja?

Ovaj konceptualni okvir je odabran iz razloga što je bio osnova za pripremu niza kvalitetnih komparativnih studija (Graf, Lassning and Powell 2012; Anderson and Oude Nijhuis 2012; Nelson 2012; Gonon and Maurer 2012; Thelen and Busemeyer 2012) koje bitno nadilaze deskripciju, uvjerljivo tumače institucionalne ishode kroz analizu strategija ključnih aktera i historijskih uvjetovanosti pojedinih kritičnih točaka (engl. critical junctures) u kojima su se događale bitne primjene u ustroju sustava. One su posljedično ograničavale spektar budućih mogućnosti stvarajući tzv. „ovisnost o putu” (engl. path dependency). U okviru šire (institucionalne) teorije javnih politika, ovaj konceptualni okvir mogli bismo smjestiti na razmeđe historijskog institucionalizma (Fioretos, Falleti and Sheingate 2013; Steinmo 2008), te institucionalizma usmjerenog akterima (Scharpf 2000).

Četiri temeljna pitanja koja uvjetuju pripadnost pojedinom režimu pretvorena su u kodove prikladne za kvalitativnu obradu podataka. To je uključivalo jezičnu prilagodbu, dodjelu jasnih operativnih definicija a onda i razradu dodatnih kodova niže razine (potkodova). Uzimajući u obzir da se radi o konceptualnom okviru nastalom u kontekstu razvijenih industrijskih demokracija, pri čemu Hrvatska ne spada u tu kategoriju, nametnula se potreba uvođenja određenog mehanizma koji bi osnažio validnost nalaza. Tu se istraživački dizajn naslanja na ideju kako je jedna od osnova učinkovitog diferenciranja sustava strukovnog obrazovanja (ne)postojanje institucionalnih aranžmana koji omogućavaju razmjenu informacija, međusobni monitoring, sankcioniranje, a onda i strukturiranu deliberaciju između 
ključnih aktera (Hall and Soskice 2001, 29-30). Točnije, postojanje i funkcionalnost takvih aranžmana uvelike je kompatibilno s postojanjem „kolaborativnih", odnosno kolektivnih sustava strukovnog obrazovanja/razvoja vještina. Potpuni izostanak takvih mehanizama čime se pitanja osposobljavanja i alokacije radne snage u potpunosti prepušta tržištu (bez potrebe za međusobnim usklađivanjem između aktera) uglavnom se vezuje uz liberalne sustave, dok se segmentalistički i državni smještaju između dva provizorna pola. Za mapiranje takvog sadržaja korišten je dodatni kod „Koordinacija” koji se primjenjivao na sve mehanizme koji omogućavaju (ili olakšavaju) usklađeno djelovanje između aktera politike strukovnog obrazovanja. Konkretnije, ovim kodom su obično mapirani sadržaji kojima su se: i) definirale ili razrađivale ovlasti pojedinih aktera politike strukovnog obrazovanja (posebice onih nedržavnih); ii) uspostavljala tijela koja su za cilj imala potaknuti/osigurati strukturiranu komunikaciju između aktera ${ }^{4}$. Sadržaj prikupljen putem ovog koda korišten je kao korektiv pri ocjenjivanju relevantnosti institucionalnih promjena, kako na razini pojedine jedinice analize tako i cjeline sustava/režima.

Kompletna lista kodova priložena je ovom radu kao Prilog 1.

Takva kodna lista primijenjena je na tekstove svih zakona (uključujući izmjene i dopune) koji direktno ili indirektno uređuju područje strukovnog obrazovanja od stjecanja hrvatske neovisnosti do danas. Ovom okviru su pridruženi svi programsko-strateški dokumenti koji uređuju područje strukovnog obrazovanja. Pritom je posljednja inačica Zakona o usmjerenom obrazovanju (Hrvatski sabor 1991) analizirana kao zasebna jedinica; s jedne strane, kao veza s socijalističkim razdobljem, s druge, kao provizorna početna točka razvoja strukovnog obrazovanja u nezavisnoj Republici Hrvatskoj. Ukupno je analizirano 29 policy dokumenata koji su popisani u Prilogu 2.

Nakon kodiranja izdvojeni su oni dokumenti kod kojih je utvrđena promjena u bilo kojoj od ključne 4 bitne institucionalne odrednice (kontrola-financiranje-izvoditelji-odnos općeg i strukovnog). Promjene u svakom od dokumenata su vrednovane u odnosu na njihov kapacitet da utječu na cjelinu funkcioniranja sustava, te da stvore ovisnost o putu. Točnije, kriteriji vrednovanja su bili kvalitativni, a ne kvantitativni primjerice, relevantnim su se nekim situacijama pokazale izmjene jednog do dva članka zakona, dok su u drugom slučaju iz daljnje analize izuzete ekstenzivne izmjene koje su se na razini pukog tehničkog usklađivanja doticale sve 4 institucionalne odrednice. Na koncu je sadržaj relevantnih epizoda korišten za izgradnju narativa o razvoju i karakteru sustava koji je izložen u sljedećem poglavlju.

4 Ovo uvelike odgovara opisu „deliberativnih institucija” u terminologiji Halla i Soskicea (2001: 30). 


\section{NALAZI}

\section{ZAKON O USMJERENOM OBRAZOVANJU IZ 1991.}

Posljednja inačica Zakona o usmjerenom obrazovanju (Hrvatski sabor, 1991) je analitički zanimljiva iz barem dva razloga. Prvo, može poslužiti kao provizorna početna točka razvoja hrvatskog sustava srednjeg (strukovnog) obrazovanja, a da pritom predstavlja i jasnu poveznicu sa socijalističkim periodom koji je nedvojbeno dio njegovog institucionalnog nasljeđa. Drugo, sadržaj ovog zakona ide u prilog argumentu o potrebi stvaranja zasebnih eksplanatornih modela za tumačenje razvoja politike strukovnog obrazovanja u tranzicijskim, postkomunističkim društvima. Konkretno, a što će biti vidljivo iz analize iznesene u sljedećim odlomcima, usmjereno obrazovanje je iznimno teško uvjerljivo svrstati pod bilo koji tip sustava/režima obuhvaćen ovim konceptualnim okvirom; čak i na razini pojedine dimenzije.

Kad je riječ o kontroli sustava srednjeg strukovnog obrazovanja, može se reći da ovaj zakonski tekst aktere središnje države stavlja u prilično snažnu poziciju. Razvlašćuju se samoupravne zajednice usmjerenog obrazovanja u korist Ministarstva kulture i prosvjete koje, među ostalim:

,- predlaže programe, oblike, opseg, kvalitetu i način zadovoljavanja potreba u usmjerenom obrazovanju (obrazovni standard usmjerenog obrazovanja u Republici);

- utvrđuje jedinstvene osnove, normative, standarde i kriterije za financiranje programa i vrednovanje rezultata rada organizacija usmjerenog obrazovanja”.

Ovo su relativno uobičajene ovlasti ministarstva zaduženog za odgoj i obrazovanje. Međutim, u tekstu zakona slijedi neobičan zaokret s obzirom da okvirne programe u rasponu od prvog do petog stupnja obrazovanja usvaja Republički fond usmjerenog obrazovanja (na prijedlog Ministarstva). Neobično je što je Fond javno tijelo pod direktnom kontrolom Vlade (pa posredno i Ministarstva), što ovakvu dinamiku predlaganja i usvajanja između ova dva tijela čini prilično nelogičnom iz upravljačke perspektive.

Kad je riječ o izvoditeljima strukovnog obrazovanja, korisno je naglasiti kako zakon propisuje da: „Organizaciju usmjerenog obrazovanja mogu osnovati skupština društveno-političke zajednice, poduzeća i druge pravne i fizičke osobe pod uvjetima utvrđenim ovim zakonom". To ukazuje na bitno širi spektar osnivača negoli je to slučaj u bilo kojem tipu državnog sustava. Doduše, sam proces osnivanja vezan je uz snažnu ulogu središnje države, do razine da u zadnjem koraku akt o osnivanju pojedine organizacije usmjerenog obrazovanja usvaja sam Sabor. 
Zakonski tekst ukazuje na jasnu i dobro razrađenu (premda ne nužno i funkcionalnu) institucionalnu vezu između obrazovnih institucija i gospodarstva. Konkretno, organizacije usmjerenog obrazovanja (škole) su kao izvoditelji stavljeni na ravnopravnu ravan s organizacijama privrede i društvenih djelatnosti; koje predstavljaju funkcionalni ekvivalent firmama u političkoj ekonomiji razvoja vještina. Također, zakon propisuje obvezu potonjih da učenicima osiguraju praksu u skladu s odredbama Republičkog fonda, a koja se može izvoditi i u školama (laboratoriji i praktikumi), kao i organizacijama privrede i društvenih djelatnosti. Odnos između referentnih organizacija uređuje se posebnim sporazumom. Ovakvu strukturu bi se s aspekta političke ekonomije razvoja vještina moglo opisati kolektivnom.

Kad je riječ o financiranju središnja država (putem Republičkog fonda) distribuira sredstva prikupljena eksplicitno navedenim izdacima na teret poduzeća (stopa $1,20 \%$ ), te osobnih prihoda (3,40\%). Po sličnom principu se, samo po nešto nižim stopama, financiraju stanovanje u učeničkim/ studentskim domovima, te subvencionirana prehrana. „Osobni i društveni” standard polaznika financiraju firme, odnosno radnici „sukladno mogućnostima”. Ukoliko su željeli pohađati programe koji nisu obuhvaćeni okvirom „pojedinačnih i zajedničkih potreba organizacija i radnih zajednica i zajedničkih potreba društva” polaznici su navedene troškove snosili sami. Ovako uređeni financijski aranžmani moglo bi se opisati dominantno državnim, ali s elementima kolektivnosti, pa čak i liberalizma.

Odnos općeg i strukovnog obrazovanja je u analizi usmjerenog obrazovanja nepostojeća kategorija jer model je upravo stvoren da bi dokinuo diferenciranje programa po toj osnovi. Može se ipak konstatirati vrlo visoka razina horizontalne i vertikalne prohodnosti temeljem većeg broja odredbi koje zbog obuhvata ovog rada nije moguće detaljnije razmatrati. No, suština je da se: i) omogućava neometan pristup visokom obrazovanju po završetku srednjoškolskog; ii) dopušta promjena programa iste razine u svakoj fazi obrazovnog pod pretpostavkom da se radi o programu koji je „srodan“; iii) ponavljačima nudi nastavak u istovrsnom ili srodnom programu na istoj i/ili na nižoj razini stručne spreme/kvalifikacije. Radi se o vrlo blago stratificiranom sustavu (srednjeg) obrazovanja u usporedbi s kasnijim razdobljima.

Konačno, koordinacija se događa na dvije razine. Na lokalnoj (općinskoj) razini propisuje se suradnja između organizacija usmjerenog obrazovanja s „organizacijama i radnim zajednicama radnika” (što su u osnovi gospodarski subjekti). Zakon ne razrađuje detaljnije mehanizme takve koordinacije. Osim toga, srodne organizacije usmjerenog obrazovanja imaju mogućnost udruživanja u zajednice usmjerenog obrazovanja s ciljem međusobnog usklađivanja, suradnje i rješavanja drugih problema. 


\section{ZAKON O SREDNJEM ŠKOLSTVU IZ 1992.}

Veliki zaokret dolazi sa Zakonom o srednjem školstvu iz 1992. (Hrvatski sabor 1992) koji je bitno izmijenio tri od četiri odrednice režima razvoja vještina, pa time i sustava srednjeg strukovnog obrazovanja u Hrvatskoj. Kad je riječ o prvoj odrednici - izvoditeljima srednjeg (strukovnog) obrazovanja; organizacije usmjerenog obrazovanja prestaju biti dijelom normativnog okvira, te ih mijenjaju tri vrste škola/programa koje poznajemo i danas: gimnazije, četverogodišnje strukovne/tehničke škole, te trogodišnje strukovne škole, koje se dijele na industrijske i obrtničkes. Nadalje, uvode se i promjene u sustav financiranja srednjeg obrazovanja i to na način da se imenuju izvori financiranja (Republika Hrvatska, županije, te Grad Zagreb) bez razrade dodatnih operativnih pitanja, u prvom redu raspodjele rashoda između nacionalne i regionalne razine. Korisno je napomenuti kako se sredstva za srednje školstvo ovim zakonom izdvajaju iz proračuna u zaseban fond pri Ministarstvu prosvjete, pri čemu je logiku te implikacije ovakvog rješenja potrebno ispitati u budućim istraživanjima. Sličan tip načelnih izmjena nalazimo i u području odnosa između općeg i strukovnog obrazovanja kroz definiranje mogućnosti ostvarivanja horizontalne prohodnosti. Ovdje se može prepoznati određena ostavština usmjerenog obrazovanja s obzirom na to da je velika ovlast ostavljena nastavničkom vijeću koje posve autonomno može odrediti strukturu dodatnih ili razlikovnih ispita koje učenik prethodno mora položiti. Ovakvo relativno decentralizirano rješenje ograničeno je isključivo odredbom da se promjena programa u pravilu događa nakon prvog razreda. Dakle, može se zaključiti kako je Zakon o srednjem školstvu iz 1992. postavio konture novog sustava srednjeg (strukovnog) obrazovanja, pri čemu je zakonski tekst relativno siromašan konkretnim provedbenim mehanizmima, među ostalim i onima koji se tiču koordinacije između bitnih aktera.

\section{ZAKON O OBRTU IZ 1993.}

Logično, brojne sadržajne nedorečenosti originalnog Zakona o srednjoškolskom obrazovanju bilo je potrebno inkrementalno popunjavati novim zakonskim rješenjima. U kontekstu razvoja strukovnog obrazovanja najvažnije izmjene donosi Zakon o obrtu iz 1993. (Hrvatski sabor 1993), koji unosi novitete u sustav kontrole sustavom srednjeg strukovnog obrazovanja, a onda uvodi i nove izvoditelje koji nisu bili prepoznati ranijim Zakonom o srednjoškolskom obrazovanju. Konkretno, izvedba trogodišnjih 
strukovnih programa za obrtnička zanimanja dobiva snažno kolektivnu notu vidljivu na više razina. Prvo, specifičan način izvedbe ovih programa koji kombinira izvedbu u školi i na radnom mjestu dobiva naziv „naukovanje" (engl. apprenticeship; nem. Lehre) koji u osnovi indicira bliskost tih programa dualnom modelu obrazovanja zemalja njemačkog govornog područja. Drugo, i s analitičkog aspekta relevantnije, direktnu kontrolu nad stručno-teorijskim i praktičnim dijelom ovakvih programa dobiva Ministarstvo gospodarstva, koje prije usvajanja pripadajućih kurikuluma (odnosno, plana i programa) mora dobiti prethodnu suglasnost Ministarstva prosvjete i Hrvatske obrtničke komore (nadalje: HOK). I dok je uloga ministarstva zaduženog za obrazovanje u osnovi očekivana, stvaranje ovlasti za HOK, posebice u fazi formulacije, predstavlja u nominalnom smislu značajno smanjenje stupnja kontrole aktera središnje države. Druga bitna promjena koju donosi ovaj zakon jest uvođenje poslodavaca/obrtnika kao izvoditelja programa za obrtnička zanimanja posve ravnopravnih obrtničkim školama, barem u dijelu praktične nastavne komponente ${ }^{6}$.

\section{ZAKON O IZMJENAMA I DOPUNAMA ZAKONA O OBRTU IZ 2001.}

Polagano izdvajanje srednjoškolskih programa za obrtnička zanimanja kao elementa srednjeg (strukovnog) obrazovanja sa izraženim elementima kolektivnog pristupa dolazi do krajnje točke usvajanjem Zakona o izmjenama i dopunama Zakona o obrtu iz 2001. (Hrvatski sabor 2001a). U segmentu kontrole uloga HOK-a dodatno je osnažena ovim zakonskim tekstom. Prvo, po prvi puta je eksplicitno definiran postupak licenciranja poslodavaca za obavljanje praktičnog dijela nastave, odnosno naukovanja. Drugo, HOK-u je propisana konzultativna uloga u definiranju cijene završnog/pomoćničkog ispita za ove tipove programa, pri čemu su redovni učenici izuzeti od financiranja ovog troška. Nadalje, učenici po završetku programa dobivaju dvojnu diplomu: onu od škole za uspješno polaganje završnog ispita, te HOK-ovu za stjecanje pomoćničkog zvanja. Konačno, vrijedi napomenuti kako je u izvedbi praktičnog dijela nominalno dodatno osnažena važnost poslodavaca kroz odredbu kako se taj segment naukovanja nužno odrađuje kod obrtnika ili u trgovačkom društvu. Ipak, vjerojatno uvažavajući poteškoće nekih naučnika u pronalaženju poslodavaca voljnih izvoditi naukovanje, ostavljena je mogućnost reteriranja na raniju poziciju izvedbe praktičnog dijela nastave i u obrtničkoj školi, pod pret-

6 Kasnije je Zakonom o izmjenama i dopunama Zakona o obrtu (Hrvatski sabor 1996) određeno kako se praktični dio nastave ne smije izvoditi isključivo u obrtničkoj školi (što je osnažilo ulogu poslodavaca/obrtnika u izvedbi), a provoditeljima naukovanja su imenovana i trgovačka društva, te trgovci-pojedinci koja obavljaju djelatnost vezanih obrta, odnosno članovi su HOK-a. 
postavkom da je to u manjem udjelu u odnosu na vrijeme provedeno kod poslodavaca. Ukupna bilanca ovog zakonskog teksta jest daljnje blago jačanje kolektivnosti u području obrazovanja za obrte.

\section{ZAKON O IZMJENAMA I DOPUNAMA \\ ZAKONA O SREDNJEM ŠKOLSTVU IZ 2001.}

Što se u međuvremenu događa na širem polju obrazovne politike? Dok se u području obrta osnažuje kolektivni pristup (središnje) države i dijela organiziranog poslovnog sektora predstavljenog u HOK-u, ostatak sustava srednjeg obrazovanja u gotovo svim dimenzijama konsolidira državni karakter. Tako iste 20o1. dolazi do usvajanja Zakona o izmjenama i dopunama Zakona o srednjem školstvu (Hrvatski sabor 20o1b), koji se u pravilu povezuje s „decentralizacijom srednjeg obrazovanja”. Ona je u suštinu svedena na jasnu podjelu financijskih odgovornosti za srednje obrazovanje između središnje i regionalne razine vlasti ${ }^{7}$, kao i uvođenje mehanizama regionalnog poravnanja razlika. Kontrolu na makro razini u ovom preslagivanju karata zadržava središnja država, odnosno Ministarstvo prosvjete, koje među ostalim donosi finalnu odluku o mreži srednjoškolskih ustanova, na prijedlog županija. Županije pak postaju isključivi osnivači javnih srednjih škola u Hrvatskoj, čime se u potpunosti uklanjaju i posljednji elementi šarolikosti koje je na ovome planu institucionalizirao sustav usmjerenog obrazovanja.

\section{ZAKON O ODGOJU I OBRAZOVANJU U OSNOVNOJ I SREDNJOJ ŠKOLI IZ 2008.}

Prvi zakon koji integrirano uređuje područja osnovnog i srednjeg obrazovanja u Hrvatskoj (Hrvatski sabor 2008) predstavlja najznačajniju konsolidaciju dominantne pozicije središnje države u sustavu srednjeg obrazovanja od donošenja Zakona o srednjem školstvu iz 1992. On uvodi važne promjene u dvije institucionalne odrednice obuhvaćene ovom analizom: kontrola, te odnos općeg i strukovnog obrazovanja ${ }^{8}$; a ovog puta su prisutni i novi mehanizmi koordinacije kompatibilni sa smjerom koji bi se mogao nazvati „državnom konsolidacijom”. Konkretno, zakonski tekst propisuje usvajanje Državnih pedagoških standarda u Hrvatskom saboru,

7 Grubo govoreći, glavni trošak središnje države jesu plaće nastavnog i stručnog osoblja, dok na županije pada teret financiranja opreme i infrastrukture škola.

8 Treba napomenuti da je ovaj zakonski tekst donio i brojne promjene u financiranju srednjeg strukovnog obrazovanja, no one su uglavnom bile tehničkog karaktera te nisu bitnije utjecale na sustav postavljen Zakonom o srednjem školstvu iz 1992, odnosno izmjenama iz 2001. Stoga te izmjene nisu detaljnije razmatrane u ovom prikazu. 
na prijedlog Vlade; dok središnji sadržajni dokument osnovnog i srednjeg obrazovanja, Nacionalni kurikulum, usvaja ministar zadužen za obrazovanje.

Nadalje, licenciranje nastavnog i stručnog osoblja u osnovnim i svim tipovima srednjih škola postaje isključivo ovlast (državnog) Nacionalnog centra za vanjsko vrednovanje obrazovanja; pri čemu: „Program, postupak i način stjecanja, izdavanja i obnavljanja licencije za rad učitelja, nastavnika, stručnih suradnika i ravnatelja te prava i dužnosti... propisuje ministar”. Specifičnosti strukovnog obrazovanja na bilo koji način nisu uvažene ovdje te nisu predviđeni nikakvi (formalni) mehanizmi uključivanja nedržavnih dionika u ovaj važan element politike strukovnog obrazovanja. Konačno, decentralizacija na provedbenoj/razini škola je izrazito sužena na način da je školama ostavljen minimalan prostor kurikularne prilagodbe koja se odnosi isključivo na fakultativni dio. Uvođenje eksperimentalnih programa također postaje moguće tek uz prethodno odobrenje resornog ministarstva.

Kad je riječ o odnosu općeg i strukovnog obrazovanja, ovaj zakonski tekst predviđa uvođenje Državne mature koja uvelike doprinosi jačanju stratifikacije unutar kompletnog sustava srednjeg obrazovanja, jasno produbljujući već postojeću hijerarhiju između tri najvažnije skupine programa. Dok učenici s diplomama gimnazijskih, te četverogodišnjih strukovnih programa imaju direktan pristup Državnoj maturi, koja ujedno postaje i „ulaznica” za pristup visokom obrazovanju, učenici koji završavaju trogodišnje strukovne programe moraju u osnovi steći diplomu nekog četverogodišnjeg (u pravilu strukovnog) programa kroz polaganje značajnog broja razlikovnih ispita. Ovakvo jasno smanjenje vertikalne prohodnosti sustava, naročito važno za trogodišnje programe, djelomično se ublažava nominalnim olakšavanjem horizontalne prohodnosti kroz uklanjanje odredbe kako se promjena programa događa u pravilu „na kraju prvog razreda”. Korisno je spomenuti i novi mehanizam koordinacije koji bi trebao podržavati proces izrade Nacionalnog kurikuluma - Vijeće za nacionalni kurikulum, koje bi se uz davanje savjeta o njegovu sadržaju trebalo baviti: „... i kvalitativnim unapređenjem odgojno-obrazovne djelatnosti na osnovnoškolskoj i srednjoškolskoj razini”. Radi se o tijelu nepoznata sastava, savjetodavnih ovlasti, a čije je imenovanje u potpunoj ovlasti ministra obrazovanja. Točnije, radi se o vrlo slabom koordinacijskom mehanizmu upitnog utjecaja na procese formulacije i provedbe obrazovne politike koja ostaje pod snažnom kontrolom aparata središnje države.

U cjelini, Zakon o odgoju i obrazovanju iz 2008. donosi značajno povećanje kontrole središnje države na razini kompletnog srednjeg obrazovanja, jačanje standardizacije na izvedbenoj razini, te produbljivanje stratifikacije, s naročitim implikacijama za trogodišnje strukovne programe. 
Ovakva značajna konsolidacija moći središnje države praćena je tek kozmetičkim mehanizmom međusektorske koordinacije u vidu Vijeća za nacionalni kurikulum? 9

\section{ZAKON O STRUKOVNOM OBRAZOVANJU IZ 2009.}

Sljedeće godine Hrvatska je dobila prvi zakon koji sveobuhvatno uređuje područje srednjeg strukovnog obrazovanja. Zakon o strukovnom obrazovanju (Hrvatski sabor 2009) donosi brojne promjene u sve četiri bitne odrednice, s prevladavajućom bilancom jačanja pozicije središnje države. U području kontrole svakako valja izdvojiti uvođenje sektorskih vijeća kao ključnih tijela za usklađivanje kvalifikacija s društvenim i potrebama tržišta rada. Radi se o strukturi koja se može smatrati svojevrsnom pretečom nacionalnog kvalifikacijskog okvira formalno uvedenog zasebnim zakonom nekoliko godina kasnije (Hrvatski sabor 2013a). U radu sektorskih vijeća ključnu ulogu imaju akteri središnje države: ministarstvo nadležno za obrazovanje, te Agencija za strukovno obrazovanje i obrazovanje odraslih (nadalje: ASOO). Ovakav nalaz je u skladu s literaturom (Powell and Trampusch 2012) koja strukture nacionalnog kvalifikacijskog okvira ne vidi kao neutralne instrumente s aspekta raspodjele moći unutar sustava (strukovnog) obrazovanja već one koji dodatno jačaju aktere središnje države. Također, strukovnim školama je ostavljena mogućnost posve autonomne prilagodbe $15 \%$ posebnih i izbornih sadržaja strukovnog kurikuluma, uz prethodne konzultacije s lokalnim akterima politike strukovnog obrazovanja.

U kontekstu izvoditelja ovaj zakon predviđa uvođenje centara kompetentnosti i tehnologija čija je glavna svrha ,... provedba i unapređenja praktične nastave ili dijela praktične nastave, te vježbi odgovarajuće struke". Ovakve centre osnivaju postojeće ustanove strukovnog obrazovanja, te su pod potpunom provedbenom ingerencijom ministarstva zaduženog za obrazovanje i ASOO-a. Zanimljivo je da osnivanje centara kompetentnosti ne prati nikakav formalni proces koordinacije s drugim, vanjskim dionicima sustava, što predstavlja još jedan prilog jačanju pozicije središnje države.

Što se tiče financiranja, ovaj zakon uređuje visinu remuneracije za polaznike strukovnih programa koju u cijelosti snosi poslodavac, i to u

9 Nasljednik ovog tijela je bilo Nacionalno vijeće za odgoj i obrazovanje čije je osnivanje predviđeno Zakonom o izmjenama i dopunama Zakona o odgoju obrazovanju 2012. (Hrvatski sabor 2012). Iako je njegov mandat i sastav uređen preciznije, a imenovanje predviđeno putem Hrvatskog sabora, ovlasti ostaju savjetodavne, a tek dvoje od četrnaest članova biva imenovano iz redova vanjskih dionika koji nisu dio sustava odgoja i obrazovanja. Postojeća istraživanja (Buković 2016, 63) ukazuju da se savjetodavni rad ovog tijela također uglavnom zanemarivao od strane donositelja odluka. 
iznosu od 10\% prosječne plaće u prvoj, $20 \%$ u drugoj, te $25 \%$ u ostalim godinama školovanja; sukladno vremenu koje učenik provede na praksi. U izvješćima Vijeća Europe (Council of Europe 2017, 5) mogu se naći upozorenja kako Hrvatska ovako niskom razinom naknade krši odredbe Europske socijalne povelje, pri čemu postojeća istraživanja ukazuju kako i takav iznos u cijelosti te redovito isplaćuje tek manji broj poslodavaca (Herceg 2010, 26; Cedefop 2019, 17).

Nadalje, u pogledu odnosa općeg i strukovnog obrazovanja, važno je istaknuti kako se planiranje broja polaznika prvih razreda srednjih strukovnih programa (među ostalim) treba temeljiti i na broju slobodnih mjesta za provedbu praktičnog dijela obrazovanja. Ovo se može gledati kao element kolektivnosti koji u teoriji može služiti kao mehanizam jačanja kvalitete strukovnih u odnosu na općeobrazovne programe. Pitanje prepreka koje učenicima trogodišnjih programa u pogledu pristupa visokom obrazovanju stvara uvođenje Državne mature je u ovom zakonskom tekstu kozmetički adresirano najavom usvajanja posebnog pravilnika. ${ }^{10}$ Odluke o promjeni programa na istoj razini kvalifikacija (horizontalna prohodnost) uglavnom su prepuštene stručnim tijelima škole, uz poštivanja uputa koje izdaje ASOO. U cjelini se može reći da ovaj zakonski tekst čini malo da prevlada značajan jaz u položaju i prestižu općeg i strukovnog obrazovanja stvoren Zakonom o odgoju i obrazovanju iz 20o8. Ova ocjena se naročito odnosi na položaj trogodišnjih strukovnih programa.

Konačno, ovaj zakonski tekst nastojao je adresirati evidentan institucionalni vakuum po pitanju koordinacije u području strukovnog obrazovanja kroz uspostavljanje Vijeća za strukovno obrazovanje. Ovo savjetodavno tijelo je po osnivanju brojalo 17 članova, uglavnom iz redova obrazovnih ustanova, te institucija zaduženih za provedbu obrazovne politike. U ovom tijelu su također zastupljeni predstavnici HOK-a, Hrvatske gospodarske

10 Pravilnik o uvjetima i načinima nastavka obrazovanja za višu razinu kvalifikacije (Ministarstvo znanosti, obrazovanja i sporta 2016) nominalno uređuje materiju vertikalne prohodnosti trogodišnjih strukovnih programa. Među ostalim određuje kako učenik trogodišnjeg programa obrazovanje može nastaviti stjecanjem četverogodišnje kvalifikacije unutar istog obrazovnog sektora, za nastavak obrazovanja mora imati prosjek od minimalno 3,5 u svakom od završenih razreda srednje škole, te propisuje da se učenik u nastavni proces može integrirati u tekućoj ili narednoj školskoj godini, a nakon polaganja razlikovnih ispita o čijem broju i strukturi odlučuje nastavničko vijeće. Iako bi provedbene implikacije ovih odredbi trebalo provjeriti zasebnim empirijskim istraživanjem, teško je vjerovati da su one uspjele bitnije adresirati nepraktičnost aranžmana u kojem se učenike trogodišnjih programa zapravo ne priprema za uspješno polaganje Državne mature već ih se usmjerava na stjecanja nove strukovne kvalifikacije. U tom kontekstu se bitno adekvatnijim čini austrijski pristup u kojem se naučnike zainteresirane za polaganje državne mature priprema tijekom školovanja, uz dvije dodatne godine redovnog školovanja koje ne služe stjecanju dodatne kvalifikacije već isključivo pripremi za polaganje mature. Pritom valja dodati i da Austrija naučnicima omogućava i alternativni pristup visokom obrazovanju kroz strukovnu maturu (Buković 2018). 
komore, Hrvatske udruge poslodavaca, sindikata, te nacionalnih saveza udruga koje predstavljaju osobe s invaliditetom. Sastav tijela je dodatno proširen izmjenama Zakona o strukovnom obrazovanju 2018. (Hrvatski sabor 2018) na 21 člana, a postojeće savjetodavne ovlasti su blago dopunjene. Iako mu je svrha trebala biti poticanje široke deliberacije i koordinacije u području politike strukovnog obrazovanja, postojeća istraživanja nisu utvrdila bilo kakav utjecaj ovog tijela na važnije sistemske odluke (Matković i sur. 2013; Buković 2018).

\section{ZAKON O OBRTU IZ 2013.}

Do gotovo potpunog uklanjanja kolektivno-korporativističkih elemenata iz programa obrazovanja za obrte dolazi 2013. Ta promjena je u kvalitativnom smislu kompletan sustav učinila gotovo u potpunosti državnim, što je stanje koje ostaje nepromijenjeno do trenutka pisanja ovog rada. Instrument tog zaokreta je novi Zakon o obrtu (Hrvatski sabor 2013b) koji je doveo do važnih izmjena u pogledu kontrole sustava srednjeg strukovnog obrazovanja. Konkretnije, evidenciju ugovora o naukovanju od stupanja na snagu ovog zakona vodi Ministarstvo poduzetništva i obrta (nadalje: MINPO), ne kao dosada HOK. Izvedbu pomoćničkog ispita preuzimaju ASOO i Nacionalni centar za vanjsko vrednovanje obrazovanja. Slijedom navedenog, potvrdu stjecanja pomoćničkog zvanja izdaje MINPO, a ne HOK kojemu je također oduzeta formalna konzultativna uloga u izradi ključnih provedbenih dokumenata poput strukovnog kurikuluma i programa pomoćničkog ispita. Koordinacija se događa isključivo na relaciji ministarstava zaduženih za obrt i obrazovanje, dok je jedina bitna ovlast koju HOK zadržava na razini izvedbe srednjoškolskih programa licenciranje obrtničkih radionica za izvedbu praktičnog dijela naukovanja. Konačno, u pogledu izvoditelja ovaj zakonski tekst donosi manju promjenu u vidu prepoznavanja zadruga koje izvode djelatnost obrta kao mogućih izvoditelja naukovanja.

\section{STRATEGIJA ZNANOSTI, OBRAZOVANJA I \\ TEHNOLOGIJE IZ 2014.}

Strategija znanosti, obrazovanja i tehnologije (Hrvatski sabor 2014) nije bitnije promijenila trend postojećeg inkrementalnog kretanja prema gotovo sustavu koji bi se cijelosti moglo opisati državnim, no dotakla se nekoliko zanimljivih elemenata ${ }^{11}$. Prvo, kad je riječ o kontroli, u dokument je inte-

11 Važno je imati na umu da strateški dokument propisuje mjere čija provedba nije jednako obvezujuća poput zakonskih odredbi. U tom smislu, nalaze vezane uz ovaj dokument treba u manjoj mjeri promatrati kao odrednice sustava već signale nositelja vlasti o željenom smjeru reformiranja sustava. Također, korisno je napomenuti da se na ovaj dokument u dijelu koji 
grirana mjera koja predviđa analizu kvalitete postojećeg sustava učenja na radnom mjestu u sklopu strukovnih programa i razvoj novog sustava. Ovdje je svakako važno istaknuti da je samo postojanje ovakve mjere u službenom strateškom dokumentu do sada prvi institucionalizirani pokušaj da se adresiraju manjkavosti u praktičnom dijelu nastave koji se izvodi kod poslodavaca, a koje je dosadašnja literatura o strukovnom obrazovanju u Hrvatskoj redovito prepoznavala. Novost u pogledu odnosa općeg i strukovnog obrazovanja je nastojanje da se postojeće manjkavosti u vertikalnoj prohodnosti učenika trogodišnjih programa adresiraju razvojem novog modela. Promjene na ovom planu su se zasada svele na neambiciozni Pravilnik o uvjetima i načinima nastavka obrazovanja za višu razinu kvalifikacije (Ministarstvo znanosti, obrazovanja i sporta 2016) opisan detaljnije u fusnoti 10. Konačno, na polju koordinacije ovaj dokument je predvidio osnivanje regionalnih kooperacijskih odbora koji su za cilj imali osnažiti upravljanje strukovnim obrazovanjem na županijskoj/regionalnoj razini. Iako su za donošenje jasnijeg zaključka potrebna dodatna empirijska istraživanja, čini se da ovi mehanizmi koordinacije do danas nisu ostvarili bitniji utjecaj na terenu.

\section{RASPRAVA I ZAKLJUČCI}

Rezultati analize ukazuju da je hrvatski sustav (srednjeg) strukovnog obrazovanja jezikom političke ekonomije razvoja vještina moguće nominalno klasificirati kao „državni s elementima krnje kolektivnosti u području obrazovanja za obrte". Kad je u pitanju prvi dio ocjene - onaj koji se tiče državnog karaktera sustava, čini se da ekstenzivna objašnjenja nisu potrebna. Gimnazijske, tehničarske, te strukovne programe u industriji i prodaji uglavnom kontroliraju, financiraju, te provode državne institucije, bilo to u djelokrugu rada središnje države bilo županija. Osim toga, jasna stratifikacija između tri skupine programa, dodatno produbljena uvođenjem Državne mature, predstavlja dodatan prilog ovakvoj ocjeni.

Drugi dio klasifikacije, onaj vezan uz „krnju kolektivnost u području obrazovanja za obrte", ipak zaslužuje nešto više pozornosti. Naime, kolektivnost u području hrvatskog strukovnog obrazovanja nije postala „krnja” u recentnom periodu. Ona je bila takva od svog uvođenja putem Zakona o obrtu iz 1993, kad je naukovanje postalo jedan od modela izvedbe programa obrazovanja za obrtnička zanimanja. To je napravljeno na način da je na prevladavajuće državnu arhitekturu sustava, postavljanu Zakonom

se tiče strukovnog obrazovanja nadovezuje i Program razvoja strukovnog obrazovanja 20162020. (Vlada RH 2016) koji neke od ovdje opisanih mjera dodatno razrađuje, a donosi i neke nove; no, s aspekta ciljeva ovog rada ne donosi ništa posebno zanimljivo te je iz tog razloga izuzet iz pregleda. 
NIKOLA BUKOVIĆ

RAZVOJ INSTITUCIONALNOG USTROJA HRVATSKE POLITIKE

STRUKOVNOG OBRAZOVANJA

o srednjem školstvu 1992, dodana još jedna ,institucionalna glazura” koja je omogućila da dio sustava funkcionira po nešto drugačijim pravilima, bez da se ugroze njegova ključna institucionalna odrednica: dominantna pozicija (središnje) države u procesima odlučivanja o sadržaju programa, standardima provedbe, te financiranju u najvećem dijelu sustava. Takva dominantna institucionalna odrednica odgovara onome što literatura prepoznaje kao „institucionalnu jezgru” (engl. institutional core; Thatcher and Cohen 2008; Boas 2007; van der Heijden 2011); dok se stvaranje ili uvođenje novih pravila pored ili povrh onih postojećih, koja također ostaju na snazi, može dovesti u vezu s konceptom slojevanja (engl. layering Fioretos, Falleti and Sheingate 2013, 8-13). Spajanjem ta dva koncepta dolazimo do opisa modela kojim je moguće tumačiti ovakav hibridni, i s aspekta učinkovitosti politika, manjkavi institucionalni ishod. Eksplanatorni model možemo nazvati „slojevanjem bez utjecaja na institucionalnu jezgru”, te se time otvara prostor uvjerljivog objašnjavanja zbog čega je „oaza kolektivnosti” u području obrta relativno jednostavno vraćena pod gotovo potpunu kontrolu središnje države odredbama Zakona o obrtu iz 2013. ${ }^{12}$

Konkretnija validacija ovakvog modela ipak pretpostavlja rekonstrukciju ciljeva, strategija i djelovanja aktera u procesima koji su u bitnome definirali strukturu hrvatskog sustava strukovnog obrazovanja. Procesi koji odgovaraju tom kriteriju su mapirani i analizirani u sklopu ovog rada. ${ }^{13}$ Sam konceptualni okvir političke ekonomije razvoja vještina nudi aktere: javne institucije zadužene za strukovno obrazovanje (neovisne o razini vlasti), organizacije poslodavaca (komorske i dobrovoljne), sindikate (u pravilu one koji djeluju na nacionalnoj razini), te relevantne političke stranke. Sljedeći logični koraci su konkretizacija istraživačkih pretpostavki koje će omogućiti kvalitetno testiranje eksplanatornog modela, te definiranje metoda prikupljanja i analize podataka.

\footnotetext{
12 Treba naglasiti kako Prijedlog Zakona o izmjenama i dopunama Zakona o obrtu, koji je u trenutku pisanja ovog rada prošao prvo čitanje u Hrvatskom saboru, ide u smjeru vraćanja većine ovlasti koje su HOK-u oduzete 2013. (HOK 2019). Ukoliko bude usvojen, ovaj zakonski tekst će također biti potrebno obuhvatiti budućim analizama.

13 Potrebno je voditi računa i o relevantnim promjenama koje ne moraju nužno biti vezane uz zakonodavne te procese razvoja strateško-programskih dokumenata. Jedan od takvih primjera je i reformiranje većine programa za obrtnička zanimanja u smjeru tzv. jedinstvenog modela obrazovanja" 2003/2004, kojim se nastojao naći svojevrsni srednji put između „dualnog” pristupa baziranog na snažnoj participaciji poslodavaca, te „klasičnog” u kojem se većina (praktične) nastave izvodi u školskom okruženju (Matković i sur. 2013, 10, 19). Iz analitičke pozicije ovog rada jedinstveni model obrazovanja i dalje odgovara kolektivnom pristupu izvedbi srednjeg strukovnog obrazovanja unatoč slabijem intenzitetu sudjelovanja poslodavaca u odnosu na dualni pa stoga nema prevelikog utjecaja na (grubo) pozicioniranje unutar tipologije. Međutim, ovaj primjer svakako ukazuje na određeni tip relevantne promjene koju ovakvim dizajnom nije moguće odgovarajuće obuhvatiti.
} 
Nalazi takvog istraživanja mogu biti višestruko korisni čak i ukoliko pojedine elemente eksplanatornog modela bude potrebno odbaciti s obzirom na to da će omogućiti dosad nepostojeću razinu uvida u funkcioniranje hrvatske politike strukovnog obrazovanja. Također, testirani istraživački dizajn mogao bi predstavljati osnovu kvalitetnog teorijski utemeljenog komparativnog istraživanja politike strukovnog obrazovanja u postkomunističkim društvima, naročito bivšim članicama Jugoslavije s kojima Hrvatska nužno dijeli značajan dio historijskog konteksta i institucionalnog nasljeđa.

\section{LITERATURA}

Anderson, Karen M. and Oude Nijhuis, Dennie. 2012. "The Long Road to Collective Skill Formation in the Netherlands". In ed. Busemeyer, Marius R. and Trampusch, Cristine. The Political Economy of Collective Skill Formation. Oxford: Oxford University Press: 101-25.

Baćević, Jana. 2016. "Education, conflict and class reproduction in socialist Yugoslavia”. In ed. Archer, Rory., Stubbs. Paul and Duda, Igor. Social inequalities and discontent in Yugoslav socialism. Oxford: Taylor \& Francis Ltd.

Boas, Taylor C. 2007. "Conceptualizing Continuity and Change: The CompositeStandard Model of Path Dependence", Journal of Theoretical Politics, 19 (1): 3354. doi: 10.1177/0951629807071016

Buković, Nikola. 2016. „Perspektiva ključnih dionika o provedbi građanskog odgoja i obrazovanja: kvalitativna analiza". U ur. Pažur, Monika. Rekonstrukcija građanskog odgoja i obrazovanja u Hrvatskoj: koncept, institucije i prakse. Zagreb: Mreža mladih Hrvatske: 58-76.

Buković, Nikola. 2018. „Analiza mogućnosti transfera politike iz austrijskog u hrvatski sustav razvoja vještina”. Suvremene teme, 9 (1): 97-118; https://hrcak.srce. $\mathrm{hr} / 203851$ (21. 7. 2019).

Busemeyer, Marius R. and Trampusch, Cristine. 2012. "The Comparative Political Economy of Collective Skill Formation”. In ed. Busemeyer, Marius R. and Trampusch, Cristine. The Political Economy of Collective Skill Formation. Oxford: Oxford University Press: 3-40.

Cedefop. 2019. Apprenticeship review: Croatia. Improving apprenticeships through stronger support and care. Luxembourg: Publications Office of the European Union. Thematic country reviews; https://www.cedefop.europa.eu/fr/publications-and-resources/publications/4173 (22. 7. 2019). doi: 10.2801/97707

Cedefop ReferNet Croatia. 2014. Apprenticeship-type schemes and structured workbased programmes. Croatia. Zagreb: Agency for Vocational Education and Training and Adult Education; http://www.refernet.hr/media/1087/apprenticeship-doc.pdf (22. 7. 2019). 
Council of Europe. 2017. Croatia and the European Social Charter; https://rm.coe. int/pdf/1680492883 (26. 7. 2019).

Crnković-Pozaić, Sanja. 2009. Transition from school to work: internships and first entry to the labour market in Croatia, Working document. European Training Foundation: Torino; https://www.etf.europa.eu/sites/default/files/m/C125783 10056925BC125766600572DC8_NOTE7XJLM2.pdf (21. 7. 2019).

Cvijanović, Vladimir and Redžepagić, Denis. 2011. "From political capitalism to clientelist capitalism? The case of Croatia”. Zbornik radova Ekonomskog fakulteta Rijeka, 29 (2): 355-72.

Doolan, Karin, Lukić, Natalija and Buković, Nikola. 2016. "The Embodiment of Class in Croatian VET System”. European Journal of Education, Research and Poli-

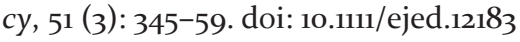

Fioretos, Orfeo, Falleti, Tulia G. and Sheingate A. 2013. Historical Institutionalism in Political Science; https://noticide.files.wordpress.com/2013/11/tulia-falleti_ historical_institutionalism_290513.pdf (22.7. 2019).

Gonon, Phillip and Maurer, Markus. 2012. "European Policy Actors as Stakeholders in the Development of the Collective Skill System: The Case of Switzerland". In eds. Busemeyer, Marius R. and Trampusch, Cristine. The Political Economy of Collective Skill Formation. Oxford: Oxford University Press: 126-49.

Graf, Lucas, Lassnigg, Lorenz and Powell, Justin J. W. "Austrian Corporatism and Institutional Change in Relationship between Apprenticeship Training and School-Based VET". In eds. Busemeyer, Marius R. and Trampusch, Cristine. The Political Economy of Collective Skill Formation. Oxford: Oxford University Press: $150-78$.

Greinert, Wolf-Deitrich. 2004. "European vocational training 'systems' - some thoughts on the theoretical context of their historical development". European Journal of Vocational Training, 32 (2): 18-25.

Hall, Peter A. and Soskice, David. 2001. "An Introduction to Varieties of Capitalism". In eds. Hall, Peter A. and Soskice, David. Varieties of Capitalism: The Institutional Foundations of Comparative Advantage. Oxford: Oxford University Press: $21-74$.

Herceg, Ivan. 2010. Povezanost kvalitete izobrazbe za obrtnička zanimanja i zapošljivosti (No. 70669); www.hok.hr/obrazovanje/projekti/povezanost_kvalitete_ strukovne_izobrazbe_za_obrtnicka_zanimanja_i_zaposljivosti (21. 7. 2019).

HOK. 2019. Najavljenim izmjenama Zakona o obrtu Vlade RH posebno se utječe na područje strukovnog obrazovanja; https://www.hok.hr/press/objave_za_medije/najavljenim_izmjenama_zakona_o_obrtu_vlade_rh_posebno_se_utjece_na_ podrucje_strukovnog_obrazovanja (27. 10. 2019).

Hrvatski sabor. 1991. „Zakon o usmjerenom obrazovanju (pročišćeni tekst)”. Narodne novine, br. 11/1991.

Hrvatski sabor. 1992. „Zakon o srednjem školstvu”. Narodne novine, br. 19/1992. 
Hrvatski sabor. 1993. „Zakon o obrtu”. Narodne novine, br. 77/1993.

Hrvatski sabor. 1996. „Zakon o izmjenama i dopunama Zakona o obrtu”. Narodne novine, br. 9o/1996.

Hrvatski sabor. 2001a. „Zakon o izmjenama i dopunama Zakona o obrtu”. Narodne novine, br. 64/2001.

Hrvatski sabor. 2001b. „Zakon o izmjenama i dopunama Zakona o srednjem školstvu". Narodne novine, br. 59/2001.

Hrvatski sabor. 2008. „Zakon o odgoju i obrazovanju u osnovnoj i srednjoj školi”. Narodne novine, br. 87/2008.

Hrvatski sabor. 2009. „Zakon o strukovnom obrazovanju”. Narodne novine, br. 30/2009.

Hrvatski sabor. 2012. „Zakon o izmjenama i dopunama Zakona o odgoju i obrazovanju u osnovnoj i srednjoj školi”. Narodne novine, br. 86/2012.

Hrvatski sabor. 2013a. „Zakon o Hrvatskom kvalifikacijskom okviru”. Narodne novine, br. 22/2013.

Hrvatski sabor. 2013b. „Zakon o obrtu”. Narodne novine, br. 143/2013.

Hrvatski sabor. 2014. „Strategija obrazovanja, znanosti i tehnologije”. Narodne novine, br. 124/2014.

Hrvatski sabor. 2018. „Zakon o izmjenama i dopunama Zakona o strukovnom obrazovanju". Narodne novine, br. 25/2018.

Jokić, Boris and Ristić Dedić, Zrinka 2014. Postati student u Hrvatskoj. Zagreb: Agencija za znanost i visoko obrazovanje; https://www.studij.hr/public/img/ publications/postati-student-u-HR/Postati_student_u_Hrvatskoj.pdf (21. 7 . 2019).

Kogan, Irene. 2008. "Education systems of Central European and Eastern European countries". In eds. Kogan, Irene, Gebel, Michael and Noelke, Clemens. Europe enlarged. A handbook of education, labour and welfare regimes in Central and Eastern Europe. Bristol: The Policy Press, University of Bristol: 7-34.

Matković, Teo. 2011. Obrasci tranzicije iz obrazovnog sustava u svijet rada u $\mathrm{Hr}$ vatskoj (Doktorska disertacija). Sveučilište u Zagrebu, Pravni fakultet/Studij socijalnog rada. Zagreb; https://bib.irb.hr/datoteka/513185.disertacija_matkovic.pdf (21. 7. 2019).

Matković, Teo, Buković, Nikola, Doolan, Karin and Lukić, Natalija. 2013. Destination Uncertain? Trends, Perspectives and Challenges in Strengthening Vocational Education for Social Inclusion and Social Cohesion. Luxemburg: Office for Official Publications of the European Communities. doi: 10.2816/15401

Milovanovitch, Mihaylo, Badescu, Mircea and Prina, Manuela. 2018. Reforms in vocational education and training in ETF partner countries. A cross-country digest of reform implementations and risks. Torino: European Training Foun- 
dation; https://www.etf.europa.eu/en/publications-and-resources/publications/reforms-vocational-education-and-training-etf-partner (22. 7. 2019). doi: $10.2816 / 82768$

Ministarstvo znanosti, obrazovanja i sporta. 2016. „Pravilnik o uvjetima i načinima nastavka obrazovanja za višu razinu kvalifikacije”. Narodne novine, br. 8/2016.

MZO. 2019. ŠeR - Školski e-Rudnik; https://mzo.hr/hr/ser-skolski-e-rudnik (21. 7. 2019).

Nelson, Moira. 2012. "Continued Collectivism: The Role of Self-Management and the Social Democratic Party in Danish Vocational Education and Training". In eds. Busemeyer, Marius R. and Trampusch, Cristine. The Political Economy of Collective Skill Formation. Oxford: Oxford University Press: 179-202.

Powell, Justin J. W. and Trampusch, Cristine. 2012. "Europeanization and the Varying Responses in Collective Skill Regimes” In eds. Busemeyer, Marius R. and Trampusch, Cristine. The Political Economy of Collective Skill Formation. Oxford: Oxford University Press: 284-313.

Rauner, Felix. 2006. "Berufliche Bildung - die europäische Perspektive”. In eds. Grollmann, Philipp, Spöttl, Georg and Rauner, Felix. Europäisierung Beruflicher Bildung - eine Gestaltungsaufgabe. Hamburg: Lit Verlag: 127-53.

Scharpf, Fritz W. 200o. "Institutions in Comparative Policy Research". Comparative Political Studies, 33 (6-7): 762-90. doi: 10.1177/001041400003300604

Thatcher, Mark and Coen, David. 2008. "Reshaping European Regulatory Space: AnEvolutionary Analysis”. West European Politics 31 (4): 8o6-36. doi: 10.1080 /01402380801906114

Thelen, Kathleen and Busemeyer, Marius R. 2012. "Institutional Change in German Vocational Training. From Collectivism toward Segmentalism”. In eds. Busemeyer, Marius R. and Trampusch, Cristine. The Political Economy of Collective Skill Formation. Oxford: Oxford University Press: 68-100.

Van der Heijden, Jeroen. 2011. "Institutional Layering: A Review of the Use of the Concept”. Politics: 2011. 31 (2): 9-18. doi: 10.1111/j.1467-9256.2010.01397.x

Vlada Republike Hrvatske. 2016. Program razvoja sustava strukovnog obrazovanja i osposobljavanja 2016-2020; https://mint.gov.hr/UserDocsImages/arhiva/290916_VRH_Program_16-20.pdf (23. 7. 2019). 


\section{Prilog 1: Popis Kodova S DEFINICIJAMA TE FREKVENCIJAMA KORIŠTENJA}

1. Kontrola [4]

Definicija: Kod se odnosi na javne ovlasti pojedinih aktera (državna/ nedržavna tijela) da kontroliraju ključne provedbene aspekte strukovnog obrazovanja.

1.1. Stvaranje, standardizacija, certifikacija [93]

Definicija: Subkod koji se odnosi na široko shvaćene ovlasti pojedinih aktera (državnih/nedržavnih) u pogledu stvaranja, osiguranja ujednačenosti (standardizacije), te dodjele potvrda (certifikata) vezano uz programe u području srednjeg strukovnog obrazovanja.

1.2. Kontrola izvedbe (izvan škole) [31]

Definicija: Subkod koji se odnosi nad ovlast kontrole izvedbe programa, naročito (ali ne isključivo) elemenata koji se odvijaju izvan škole (s obzirom na to da je školski dio izvedbe u pravilu u nadležnosti državnih ministarstava i agencija/izuzetak period samoupravljanja; međutim, u pravilu kodirani i svi elementi koji se odnose na srednje školstvo općenito).

1.3. Stupanj nadzora (mogućnost lokalne prilagodbe) [19]

Definicija: Subkod koji se odnosi na razinu u kojoj direktni provoditelji (škole, druge javne institucije, poslodavci) imaju ovlast odstupanja/prilagodbe nacionalnih programa/kurikuluma.

2. Izvoditelji obrazovanja/obuke [2]

Definicija: Kod koji se odnosi na mjesta izvedbe strukovnih programa.

2.1.Firme (uključujući obrte) [22]

Definicija: Firme kao izvoditelji dijela programa strukovnog obrazovanja. Uključuje i obrte.

2.2. Druge organizacije [13]

Definicija: Ostale organizacije (javne ili privatne) ovlaštene izvoditi dio programa strukovnog obrazovanja.

2.3. Škole [26]

Definicija: Škole kao izvoditelji programa strukovnog obrazovanja.

3. Financiranje izvedbe [1]

Definicija: Odnosi se na izvore financiranja na koje se oslanjaju programi strukovnog obrazovanja.

3.1. Središnja država [11]

Definicija: Subkod koji se odnosi na financiranje izvedbe programa strukovnog obrazovanja od strane ministarstava ili agencija središnje države. 


\section{2. Županije [6]}

Definicija: Subkod koji se odnosi na županijsko financiranje izvedbe programa strukovnog obrazovanja.

3.3. Firme [6]

Definicija: Subkod koji se odnosi na financiranje izvedbe programa strukovnog obrazovanja od strane poslodavaca, bilo kroz direktne uplate polazniku, bilo kroz osiguravanje infrastrukturnih preduvjeta, financiranje rada mentora i slično.

3.4. Učenici/polaznici [5]

Definicija: Subkod koji se odnosi na situacije u kojima dio ili cjelinu izvedbe programa strukovnog obrazovanja moraju financirati učenici, odnosno njihove obitelji.

4. Odnos strukovnog i općeg obrazovanja [o]

Definicija: Kod koji se općenito odnosi na razlike u statusu i atraktivnosti programa općeg i strukovnog obrazovanja među općom populacijom, nastavnicima (stručnim osobljem), te učenicima. U pravilu se tiče institucionalnog okvira i pojedinih mjera koje doprinose stvaranju takvih razlika.

4.1. Pristup strukovnom vs općem [7]

Definicija: Subkod koji se odnosi na kompetitivnost upisa strukovnih u odnosu na općeobrazovne programe.

4.2. Horizontalna prohodnost [12]

Definicija: Subkod koji se odnosi na mogućnosti/aranžmane prelaska/ prebacivanja iz pojedinog programa strukovnog obrazovanja u druge strukovne ili opće programe na istoj razini obrazovanja.

4.3. Vertikalna prohodnost [14]

Definicija: Subkod koji se odnosi na mogućnosti učenika koji završavaju strukovne programe da nastave obrazovanje na tercijarnoj razini.

5. Koordinacija [40]

Definicija: Odnosi se na sve mehanizme koji za cilj imaju osigurati/ olakšati usklađeno djelovanje aktera strukovnog obrazovanja.

\section{PRILOG 2: POPIS DOKUMENATA OBUHVAĆENIH ANALIZOM}

Zakon o Hrvatskom kvalifikacijskom okviru (NN 22/2013)

Zakon o obrtu

- Zakon o obrtu (NN 77/1993)

- Zakon izmjenama i dopunama Zakona o obrtu (NN 9o/1996; 64/2001; 68/2007)

- Zakon o obrtu (NN 143/2013)

Zakon o odgoju i obrazovanju u osnovnoj i srednjoj školi 
- Zakon o odgoju i obrazovanju u osnovnoj i srednjoj školi (87/20o8)

- Zakon o izmjenama i dopunama Zakona o odgoju i obrazovanju u osnovnoj i srednjoj školi (NN 86/2009; 92/2010; 90/2011; 16/2012; 86/2012; 94/2013; 152/2014; 7/2017; 68/2018)

Zakon o srednjem školstvu

- Zakon o srednjem školstvu (NN 19/1992)

- Zakon o izmjenama i dopunama Zakona o srednjem školstvu (NN 27/1993; 50/1995; 59/2001; 81/2005)

- Zakon o dopunama Zakona o srednjem školstvu (NN 114/2001)

Zakon o strukovnom obrazovanju

- Zakon o strukovnom obrazovanju (NN 30/2009)

- Zakon o izmjenama i dopunama Zakona o strukovnom obrazovanju (NN 25/2018)

Zakon o usmjerenom obrazovanju (pročišćeni tekst; NN 11/1991)

Pravilnik o uvjetima i načinima nastavka obrazovanja za višu razinu kvalifikacije (NN 8/2016)

Strategija obrazovanja, znanosti i tehnologije ( NN 124/2014)

Strategija razvoja sustava strukovnog obrazovanja u Republici Hrvatskoj 2008-2013.

Program razvoja sustava strukovnog obrazovanja i osposobljavanja 2016-2020.

\section{SUMMARY}

\section{INSTITUTIONAL DEVELOPMENT OF CROATIAN VOCATIONAL EDUCATION POLICY}

The absence of an adequate theoretical and conceptual framework dictates that any relevant institutional analysis of Croatian vocational education policy requires a separate, tailor-made explanatory model. Consequently, elements of the political economy of skill formation, a broadly acclaimed conceptual framework, were modified for coding all policy documents governing Croatian vocational education system since the country's independence. Results of such qualitative analysis indicate that the existing vocational education system is best described as "statism with elements of partial collectivism in training for crafts"; while the dominant mechanism behind it as "layering without affecting the institutional core". Testing this mechanism could pave the way to a deeper understanding of Croatian vocational education policy; but also, more ambitious comparative research within the context of post-communist societies.

KEYWORDs: education policy, vocational education, skill development, Croatia. 